Jurnal Pendidikan Ilmu Pengetahuan Sosial Indonesia is licensed under A Creative Commons Attribution-Non Commercial 4.0 International License.

\title{
Kualitas Pembelajaran Etika Lingkungan Bagi Siswa SeKolah SMA NEGERI 3 SUNGAI KAKAP
}

\author{
Dony Andrasmoro ${ }^{1)}$, Ihsan Nurhakim ${ }^{2)}$, Mustofa ${ }^{3)}$,Galuh Bayuardi ${ }^{4)}$ \\ ${ }^{1)}$ IKIP PGRI Pontianak, Pontianak, Indonesia \\ Email : donny.andrasmara@gmail.com \\ ${ }^{2)}$ IKIP PGRI Pontianak, Pontianak, Indonesia \\ Email: Ihsannurhakim08@gmail.com \\ ${ }^{3)}$ IKIP PGRI Pontianak, Pontianak, Indonesia
}

\begin{abstract}
Abstrak. Tujuan penelitian adalah membangun kesadaran lingkungan dengan pendekatan penanaman etika lingkungan di sekolah melalui pelajaran geografi materi lingkungan hidup kelas XI di SMA Negeri 3 Singai Kakap. Permasalahan bagaimana bersikap, menghargai dan merawat lingkungan sekitar agar tetap lestari, kondisi dan fenomena rendahnya kesadaran dan pola perilaku siswa di SMA Negeri 3 Sungai Kakap harus mendapatkan perhatian dan dukungan strategis dalam menjaga lingkungan yaitu dengan pendekatan etika lingkungan. Metode penelitian ini kualitatif dengan pendekatan fenomenologi berbasis first-hand experiences di mana sumber informasi responden sebagai subjek yang mengalami secara langsung aspek permasalahan lingkungan yang terjadi. Hasil penelitian ini menitikberatkan kepada permasalahan lingkungan sekolah yaitu kondisi siswa dalam pengelolaan materi lingkungan hidup, dengan pendekatan kualitas pembelajaran tiga komponen dalam pendidikan sekolah yaitu kognitif, afektif dan psikomotor. Komponen penguatan kualitas pendidikan untuk siswa berdampak terhadap hasil perubahan etika lingkungan berdasarkan sikap yang tidak peduli menjadi kepedulian kegaitan nyata. Penanaman kode etik kepada siswa dilakukan berdasarkan implementasi penguatan etika lingkungan pada pendekatan Silabus dan implementasi Rencana Pelaksanaan Pembelajaran (RPP) berbasis kurikulum monolitik dengan penguatan 5 komponen yaitu : penguatan mata pelajaran berdiri sendiri, persiapan pelajaran lebih mudah dan bahan dapat diketahui di dalam silabus, pengetahuan siswa lebih fleksibel, pengelolaan waktu kondisional, pengelolaan tujuan efektif dan efisien, pengelolaan evaluasi lebih jelas dan terarah. Aspek pengelolaan pembelajaran berdampak Sustainable Development Goals. Aspek perubahan sikap siswa didorong oleh tata kelola dan aturan yang ada dalam inovasi pengelolaan RPP dengan pendekatan pengauatan etika lingkungan dan mendukung pembangunan berkelanjutan.
\end{abstract}

Kata Kunci : Etika; lingkungan; Siswa

\section{Pendahuluan}

Perhatian terhadap pola dan perilaku siswa tercermin dari pola kedisiplinan dan kepedulian. Permasalahan lingkungan terjadi akibat dari pola perilaku yang kurang disiplin dan kurang membangun kesadaran akan pentingnya lingkungan hidup bagi kehidupan sehari-hari. Terjadinnya bencana alam rata-rata terjadi dari kurangnya kedisiplinan masyarakat terhadap pemanfaatan alam berlebihan. Peran dan fungsi etika lingkungan pada pemanfaatan lingkungan alam yang belum melekat pada masyarakat Indonesia bahwa rata-rata masyarakat indonesia belum memperhatikan terhadap resiko kebencanaan, dengan diterapkannya nilainilai dalam beretika terhadap lingkungan didalam perangkat pembelajaran, akan memberikan sebuah dampak perubahan kearah yang positif yaitu siswa mampu mengendalikan diri dalam bersikap peduli terhadap lingkungan. Oleh karena itu menurut (Miftahul Huda Atok dkk, 2019:63) dalam menerapkan etika lingkungan yang seimbang (1) Manusia sebagai bagian dari lingkungan merupakan pelaku utama dalam lingkungan, sehingga perlu menyayangi semua kehidupan dan lingkungan selain diri sendiri, (2) manusia sebagai bagian dari lingkungan merupakan pelaku utama dalam pengelolaan lingkungan, sehingga harus selalu berupaya untuk menjaga kelestarian, keseimbangan, dan kelestarian alam, (3) Bijaksana dalam pemanfaatan sumber daya alam terbatas, (4) Adanya lingkungan disediakan bukan untuk diri sendiri tetapi untuk semua makhluk hidup.

Kondisi krisis lingkungan akibat langsung dari pengelolaan lingkungan hidup yang "nir-etik" artinya, manusia melakukan pengelolaan sumber-sumber alam hampir tanpa peduli terhadap peran etika. Dengan demikian dapat dikatakan bahwa krisis ekologis yang dihadapi manusia berakar dari krisis etika dan moral. Manusia tidak menyadari manfaat dan nilai guna lingkungan alam dalam kehidupan sehari-hari. Apabila peran utama manusia dalam melakukan aktivitas terhadap lingkungan yang berlebihan akan menimbulkan konflik antara alam dan manusia itu sendiri. Isu-isu permasalahan lingkungan akan menghadirkan permasalahan etika yang lebih parah dan terjadi polarisasi masalah dan konflik. Pada dasarnya alam 
sudah diakui sebagai aset berharga, tetapi kenyataannya banyak terjadi kerusakan pada alam tersebut. isu kerusakan alam juga mempengaruhi kepada peran generasi manusia mendatang, dalam hal ini teori etika lingkungan memberikan bobot dan peran kepada generasi manusia mendatang dalam membahas isu lingkungan. Secara teori apa yang kita lakukan terhadap alam hari ini akan mempengaruhi kelangsungan lingkungan hidup dimasa mendatang. Pernyataan ini turut memunculkan beberapa pandangan tentang etika lingkungan dalam pendekatan pada alam dan lingkungan.

Peran etika mampu mengoptimalkan pemahaman tentang lingkungan pada masyarakat sekolah sehingga memberikan manfaat terhadap pengelolaan hasil belajar dan semangat siswa dari pola dan perilaku keseharian siswa. Pemberdayaan dan sosialisasi tentang etika lingkungan di sekolah tetap harus didorong oleh guru bukan hanya mata pelajaran geografi tetati sudah harus merambah kepada ranah keilmuan lain, dalam hal ini sebagai daya dukung kesadaran dan resiko yang diakibatkan terhadap kerusakan lingkungan hidup baik dari kerusakan ekologis hinga ekosistem lingkungan.

Mendorong siswa aktif dalam pengelolaan pembelajaran oleh guru sangat penting dilakukan, karena dari peran aktif siswa akan tercipta kepedulian yang lebih komperhensif dalam membangun tata kelola dan aturan sekolah walaupun peran siswa bukan di bangun kesadarannya melalui sekolah saja tetapi modal pembangunan kedisiplinan dan kesadaran lingkungan di sekolah akan memberikan dampak pola perilaku siswa di lingkungan masyarakat. Sekolah sebagai agen fasilitator perubahan dan siswa sebagai komponen pelaku dalam mendukung perubahan yang akan membawa dampak positif terhadap kedisiplinan dan kesadaran bersama.

Kualitas pembelajaran akan terlaksana dengan baik harus didukung dengan sistem tata kelola sekolah yang berbasis pola perubahan sikap dan kedisiplinan oleh karena itu peran lingkungan hidup harus didukung dengan pelaksanaan pembelajaran, implementasi melalui kurikulum pembelajaran, keterkaitan tema pelajaran terhadap lingkungan dan adanya mekanisme dan kesepakatan bersama untuk memperoleh kesuksesan dengan cara menjaga dan merawat lingkungan hidup.

Dorongan terhadap siswa tetap diarahkan untuk berfikir kritis dan kreatif, aspek ini harus dilakukan guru dalam pembelajaran dengan memberikan pendekatan dan stimulus berbasis kedisiplinan lingkungan hidup dengan pengembangan proses berfikir kreatif (creative thinking), pengelolaan bekal ketrampilan dalam kehidupan siswa (life skil), dan melakukan pengelolaan kehidupan belajar yang bahagia, menyenangkan (joyful learning). Basis pembelajaran etika lingkungan disekolah harus diarahkan pada pola perilaku siswa dengan sentuhan-sentuhan nyata di lingkungan sekolah, karena perubahan sikap kedisiplinan akan mudah dilakukan dengan membangun perilaku praktek langsung dengan bekal ketrampilan siswa dalam mengelola lingkungan hidup. Optimalisasi program etika lingkungan di sekolah akan memberikan daya dukung motivasi siswa dalam memperoleh hasil belajar yang lebih baik.

\section{METODE}

Metode yang digunakan adalah kualitatif dengan pendekatan fenomenologi, bahwa fokus dalam penelitian ini adalah bentuk perubahan etika siswa dalam pengelolaan perubahan sikap etika lingkungan siswa di SMA Negeri 3 Sungai Kakap. Pendekatan fenomenologi bertujuan untuk menggambarkan makna dari pengalaman hidup yang dialami oleh semua siswa SMA Negeri 3 Sungai Kakap secara individu, tentang konsep atau fenomena tertentu dengan mengeksplorasi struktur kesadarannya. Secara harfiah fenomenologi mempelajaran pengalaman, penampakan, segala yang muncul dari pengalaman dan cara kita mengalami sesuatu dan makna yang kita miliki dalam pengalaman kita. Fokus dalam penelitian fenomenologi bukan hanya sekedar fenomena, akan tetapi pengalaman sadar dari sudut pandang orang pertama atau yang mengalaminnya secara langsung (Kuswarna: 2009:22). Dalam hal ini pengalaman sikap siswa dalam kehidupan sehari-hari secara psikologis terhadap pengelolaan kesadaran siswa di sekolah dan implermentasi kesadaran terhadap lingkungan di luar sekolah atau masyarakat melalui perangkat dan mekanisme belajar pada mata pelajaran geografi kelas XI.

\section{HASIL DAN PEMBAHASAN}

\section{a. Lokasi Penelitian}

Penelitian dilaksanakan di SMA Negeri 3 Sungai Kakap, Kecamatan Sungai Kakap Kabupaten Kuburaya. Pelaksanaan penelitian dilaksanakan sebanyak 3 kali pertemuan dari tanggal 26 Juli sampai dengan 23 Agustus 2019

\section{b. Pengelolaan Kualitas Pembelajaran Berbasis Etika Lingkungan Di Sekolah \\ 1. Silabus}

Permasalahan yang dihadapi adalah guru dalam pengelolaan, peningkatan dan pemberdayaan produktifitas daya tarik materi adalah tergantung dari bagaimana guru dapat mengembangkan kreatifitas melalui perangkat dasar yaitu silabus pembelajaran. Dalam aspek ini pengembangan silabus dilakukan dengan pendekatan prinsip-prinsi pengembangan yang baik meliputi :

a) Ilmiah : Keseluruhan materi dan kegiatan yang menjadi muatan dalam silabus harus benar dan dapat dipertanggung jawabkan secara keilmuan.

b) Relevan : Cakupan, kedalaman, tingkat kesukaran dan urutan penyajian materi dalam silabus sesuai dengan tingkat perkembangan fisik, intelektual, sosial, emosional, dan spiritual siswa.

c) Sistematis : Komponen-komponen silabus saling berhubungan secara fungsional dalam mecapai kompetensi. 
d) Konsisten : Ada hubungan yang konsisten (ajeg, taat asas) antara kompetensi dasar, indikator, materi pokok, kegiatan pembelajaran, sumber belajar, dan system penilaian.

e) Memadai : Cakupan indikator, materi pokok, kegiatan pembelajaran, suber belajar, dan sistem penilaian cukup untuk menunjang pencapaian kompetensi dasar.

f) Aktual dan kontekstual Cakupan indikator, materi pokok, kegiatan pembelajaran dan sitem penilaian memperhatikan perkembangan ilmu, teknologi dan seni mutakhir dalam kehidupan nyata dan peristiwa terjadi.

g) Fleksibel Keseluruhan komponen silabus dapat mengakomodasi variasi siswa, proses pembelajaran dapat dilakukan secara kontekstual, yang mengaitkan isu-isu lingkungan yang terjadi sekarang ke dalam pembelajaran.

h) Menyeluruh : Komponen silabus mencakup keseluruhan ranah kompetensi (kognitif, afektif dan psikomotorik)

i) Desentralistik : Pengembangan silabus ini bersifat desentralistik, berarti kewenangan pengembangan silabus bergantung pada daerah masing-masing bahkan sekolah masing-masing.

\section{Rencana Pelaksanaan Pembelajaran (RPP)}

RPP merupakan perencanaan jangka pendek yang dibuat oleh guru untuk memperkirakan atau memproyeksikan seluruh kegiatan pembelajaran yang akan dan harus dilakukan oleh guru maupun siswa. Berfungsi kesiapan guru dalam melakukan kegiatan pembelajaran, dan untuk mengefektifkan kegiatan pembelajaran sesuai dengan yang telah direncakan. RPP mencakup: 1) data sekolah/madrasah, mata pelajaran, dan kelas/semester; 2) materi pembelajaran; 3) alokasi waktu; 4) KI, KD. Indikator pencapaian kompetensi; 5) deskripsi materi pembelajaran; 6) kegiatan pembelajaran; 7) penilaian; dan 8) media/alat, bahan dan sumber belajar.

Penjelasan indikator sintak RPP di atas sudah baik namun masih perlu pengembangan yang lebih, sesuai dengan kebutuhan guru yang menyampaikan materi pembelajaran dan untuk memberikan suatu gambaran dalam merumuskan dan mengembangkan RPP.

Maka sebaiknya dalam perancangan Rencana pelaksanaan (RPP) di dalam penelitian ini perlu rencana pembelajaran yang terperinci dan materi pembelajaran geografi dengan tema lingkungan hidup untuk meningkatkan etika lingkungan yang mengacu pada silabus yang bersifat aktual, factual, konseptual dan kontekstual di laksanakan di kelas, laboratorium, lapangan atau alam sekitar sekolah untuk mempraktekan, menggambarkan, memproyeksikan, seluruh kegiatan pembelajaran yang harus dan akan dilakukan oleh guru dan siswa dengan komponen sebagai berikut yaitu:1) identitas sekolah; 2) mata pelajaran; 3) kelas; 4) materi pokok; 5) tema lingkungan hidup; 6) alokasi waktu; 7) kompeten inti; 8) kompetensi dasar; 9) indikator pencpaian kompetensi; 10) tujuan pembelajaran; 11) deskripsi materi pembelajaran; 12) pendekatan metode dan model pembelajaran; 13) media, alat, bahan, dan sumber belajar; 14 langkah-langkah kegiatan pembelajaran; 15) penilaian; 16) identitas pembuat RRP; 17) lembar kerja dan 18) lampiran penilaian.

\section{Pengelolaan Berdasarkan Materi Pembelajaran Lingkungan Hidup}

Lingkungan hidup atau ekosistem dapat dibedakan menjadi dua, yaitu lingkungan hidup fisik dan lingkungan sosial. Lingkungan fisik dapat berupa udara, tanah, air, flora, dan fauna, sedangkan lingkungan sosial berupa hubungan antara individu atau kelompok/golongan. Komponen lingkungan dapat dibedakan menjadi komponen benda hidup (biotik) manusia, hewan, dan tumbuh-tumbuhan dan komponen benda mati (abiotik) udara, tanah, dan air. Baik yang bersifat biotik maupun abiotik merupakan satu kesatuan yang disebut ekosistem. Meningkatnya jumlah penduduk menyebabkan meningkatnya kebutuhan, baik kebutuhan primer maupun sekunder. Makin meningkatnya kebutuhan, menyebabkan makin menipisnya atau habisnya sumber daya alam.

1. Sisa-sisa pengolahan limbah berbagai industri berakibat kerusakan lingkungan atau berubahnya fungsi lingkungan karena pencemaran.

2. Pencemaran udara disebabkan bocornya pabrik pestisida Bhopal/India, bocornya pusat listrik tenaga nuklir di Chernobyl/Rusia telah banyak makan korban manusia.

3. Hujan asam di kota-kota industri karena udara sudah kotor, asap sangat mengganggu kesehatan penduduk.

4. Bencana kekeringan berkepanjangan di Ethiopia (Afrika) 1980, menyebabkan gagal panen karena penggundulan hutan, korban kelaparan, kematian penduduk. Keseluruhan permasalahan tersebut bersumber pada rangkaian jumlah pertumbuhan penduduk makin besar; sumber daya alam makin menipis/habis; dan ekosistem yang beralih fungsi dan makin jelekarena eksploitasi yang berlebihan. Konservasi, yaitu perlindungan terhadap ekosistem perlu terwujud agar terjadi keseimbangan ekosistem dan dapat mendukung upaya peningkatan kesejahteraan umat manusia.

\section{c. Pengelolaan Perangkat Pembelajaran Berbasis Etika Lingkungan Sekolah}

Pelaksanaan pembelajaran Pelaksanaan pembelajaran merupakan implementasi dari Rencana Pelaksanaan Pembelajaran yang meliputi kegiatan pendahuluan, inti, dan penutup, adapun penjelasannya sebagai berikut :.

\section{a) Kegiatan pendahuluan}


Pendahuluan merupakan kegiatan awal dalam suatu pertemuan pembelajaran yang ditujukan untuk membangkitkan motivasi dan memfokuskan perhatian peserta didik untuk berpartisipasi aktif dalam proses pembelajaran (Abdul Gafur, 2012: 174). Dalam kegiatan awal ini guru memberikan penekanan dan pandangan tentang pengetahuan yang berkaitan dengan lingkungan dan pentingnya beretika terhadap lingkungan bagi siswa sekolah SMA N 3 Sungai Kakap, agar peserta didik memiliki rasa peduli yang tinggi terhadap lingkungan dengan berperan aktif dalam memelihara dan menjaga lingkungan dengan beretika yang ramah terhadap lingkungan.

\section{b) Kegiatan inti}

Kegiatan inti merupakan proses pembelajaran untuk mencapai Kompetensi Dasar. Kegiatan pembelajaran dilakukan secara interaktif, inspiratif, menyenangkan, menantang, memotivasi siswa untuk berpartisipasi aktif, serta memberikan ruang yang cukup bagi prakarsa, kreativitas, dan kemandirian sesuai bakat, minat, dan perkembangan fisik serta psikologis siswa (Abdul Gafur, 2012: 174). Pada kurikulum 2013, kegiatan pembelajaran dilakukan melalui proses eksplorasi, elaborasi, dan konfirmasi. Pada kegiatan eksplorasi, guru melibatkan siswa untuk mencari informasi yang luas mengenai materi pembelajaran tentang etika lingkungan, dari bagaimana. Kegiatan elaborasi, guru memberikan kesempatan siswa untuk berfikir, menganalisis, dan menyelesaikan masalah melalui tugas-tugas pada materi lingkungan hidup. Kegiatan konfirmasi memberikan kesempatan kepada siswa memperoleh umpan balik pembelajaan, penguatan pemahaman dan pembenahan kesalahpahaman dalam pembelajaran tentang lingkungan hidup.

Pada kurikulum 2013, kegiatan inti lebih menuntut guru untuk membawa siswa berfikir melalui pendekatan saintifik yaitu dengan mengamati, menanya, menalar, mencoba, dan membentuk jejaring. Mengamati memberikan kesempatan peserta didik untuk melakukan pengamatan melalui kegiatan melihat, menyimak, mendengar, dan membaca. Menanya memberikan kesempatan siswa untuk membangkitkan rasa ingin tahu, minat, dan perhatian terhadap proses pembelajaran. Menalar memberikan kesempatan siswa untuk berfikir logis atas fakta yang ada. Mencoba memberikan kesempatan siswa untuk membayangkan dan membuktikan demi pengembangan tujuan belajar yaitu sikap, pengetahuan, dan keterampilan. Membentuk jejaring memberikan kesempatan siswa untuk mengemukakan ide menggunakan kata-kata lisan, grafik, tabel, diagram, dan presentasi informasi lainnya.Dari tahap demi tahap proses yang dilalui oleh peserta didik diarahkan memahami tentang etika lingkungan, bagaimana etika yang seharusnya dilakukan terhadap lingkungan, dengan melakukan aksi etika ramah lingkungan dengan menanam pohon, memberi pot bunga dimasing-masing kelas dan tidak membiang sampah sembarangan.

c) Kegiatan penutup

Penutup adalah kegiatan akhir pembelajaran. Menurut Abdul Gafur (2012: 174) penutup merupakan kegiatan yang dilakukan untuk mengakhiri aktivitas pembelajaran yang dapat dilakukan dalam bentuk rangkuman atau kesimpulan, penilaian dan refleksi, umpan balik, dan tindak lanjut. Merangkum pelajaran tentang etika lingkungan yang disampaikan kepada peserta didik, agar ada sebuah penguatan dan umpan balik terhadap apa yang telah dipelajari dan disampaikan saat proses pembelajaran dan diharapkan semuanya dapat diaplikasikan dalam tindakan beretika terhadap lingkungan dengan menjaga keseimbangan lingkungan. Jadi pada kegiatan penutup ini, pembelajaran diakhiri dengan melihat kembali pelajaran yang telah dilakukan dan mempersiapkan materi pelajaran berikutnya.

d) Evaluasi / penilaian dalam pempelajaran

Instrumen penilaian menyatakan bahwa nilai proses pembelajaran geografi sejatinya menggunakan pendekatan penilaian kemampuan kognitif, bentuk yang otentik (authentic assessment) yang menilai kesiapan siswa, proses dan hasil belajar secara utuh. Keterpaduan penilaian ketiga komponen tersebut akan menggambaran kapasitas, gaya dan perolehan belajar siswaatau bahkan mampu menghasilkan dampak instruksional (instructional effect) dan dampak pengiring (nurturant effect) dari pembelajaran.

Hasil penilaaian otentik dapat digunakan oleh guru untuk merencanakan program perbaikan (remedial), pengayaan (enrichment), atau pelayanan konseling . Hasil penilaian otentik juga dapat digunakan sebagai bahan untuk memperbaiki proses pembelajaran sesuai dengan standart penilaian pendidikan.

\section{d. Fenomena hasil Belajar Siswa terhadap pola Perilaku Siswa di Sekolah}

Hasil belajar siswa pada pengelolaan perlindungan lingkungan hidup akan di kelola berdasarkan ranah kognitif, afektif dan psikomotorik. Daya dukung ini akan memberikan informasi apakah siswa memiliki komitmen yang kuat dalam penanaman Sikap peduli lingkungan dapat muncul setelah beberapa tahapan dipenuhi yaitu, pengetahuan (knowing), pelaksanaan (acting), dan kebiasaan (habbit). Pola perilaku perubahan ini mendorong bahwa siswa harus berubah dalam penguatan dan kesadaran terhadap lingkungan sekitar. Pengelolaan hasil belajar dalam implementasi materi Lingkungan Hidup pada sub materi Etika Lingkungan di kelola melalui 3 aspek yaitu : Aspek Kognitif, Aspek Afektif dan Aspek Psikomotor. Penilaian yang dilakukan oleh guru bersama peneliti untuk mengukur capaian pembelajaran setelah melalui proses pembelajaran etika 
lingkungan, maka hasil belajar siswa di ukur dengan tiga jenis evaluasi pembelajaran yaitu, kemampuan kognitif, afektif dan psikomotorik.

Hasil belajar siswa pada penilaian kognitif berdasarkan kajian di lakukan di dalam kelas dengan nilai rata-rata kelas 78,8 dengan prsentase ketutantasan $82,4 \%$ dengan memenuhi ketuntasan belajar secara klasikal telah mencapai Kreteria ketuntasan Minimal $(\mathrm{KKM}) \geq 75$, sehingga hasil rata-rata kognitif siswa berdasarkan nilai rata-rata sangat baik.

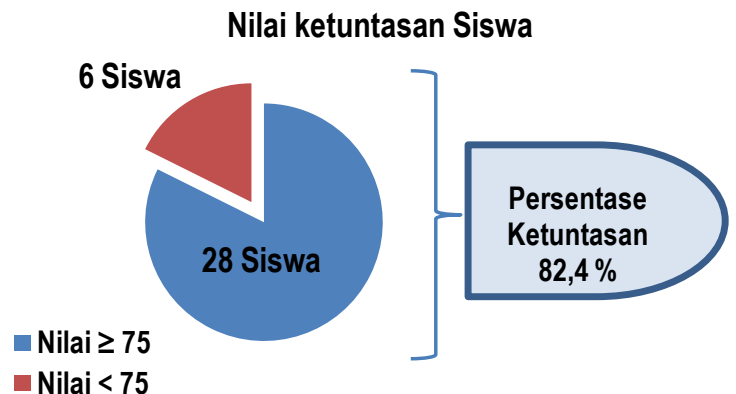

Gambar 1.1. Nilai ketuntasan Siswa

Hasil penilaian afektif siswa SMA Negeri 3 Sungai Kakap dapat dilakukan dengan aspek pengelolaan sikap berdasarkan aspek penguatan bagaimana siswa melakukan kerja sama, pola perilaku jujur, tanggung jawab terhadap apa yang menjadi tugasnya, disiplin dalam menghadapi kehidupan. Sehingga diperoleh jumlah rata-rata afektif siswa di kelas 68,75\% masuk katagori Baik.

Hasil belajar siswa SMA Negeri 3 Sungai Kakap pada katagori Psikomotorik dengan katagori penilaian bertanya, menjawab, bekerjasama, memberi pendapat, penguatan kondisi minat dengan nilai persentase $71 \%$ sebagai katagori Aktif. Aspek ini masuk dalam ranah aktif karena berkisar antara 70\%-84\%.

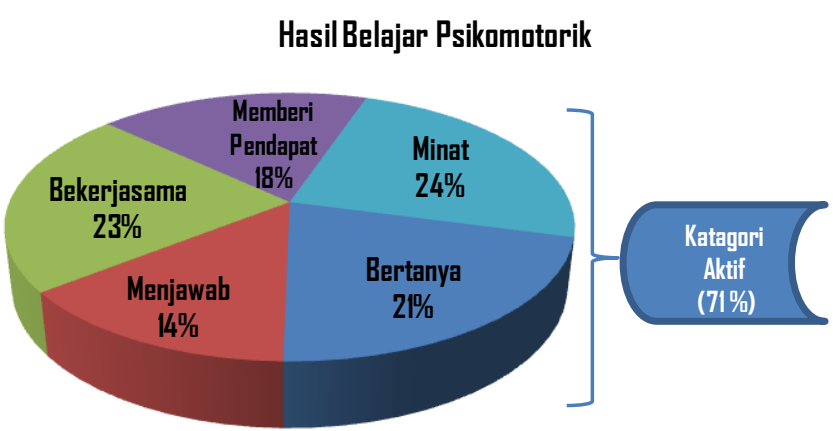

Gambar 1.2. Hasil Belajar Psikomotorik

\section{KESIMPULAN}

Berdasarkan hasil penelitian dan pembahasan yang telah diuraikan diatas maka Pengelolaan Kualitas Pembelajaran Berwawasan Etika Lingkungan pada Hasil Belajar siswa di
SMA Negeri 3 Sungai Kakap Kabupaten Kuburaya sebagai berikut :

1. Pengelolaan Kualitas Pembelajaran Berwawasan Etika Lingkungan Melalui Pengaplikasian Perangkat Pembelajaran Pada Hasil Belajar Pendidikan Lingkungan Hidup Siswa di SMA Negeri 3 Sungai Kakap Kabupaten Kubu Raya dengan pendekatan dan pemanfaatan silabus, Rencana Pelaksanaan Pembelajaran (RPP), dan pengelolaan materi. Pengelolaan tiga komponen tersebut di upayakan dalam pengelolaan dan implementasi pendekatan etika dengan menitik beratkan pada penguatan dan pembangunan karakter siswa.

2. Pengelolaan perangkat pembelajaran melalui kurikulum dalam proses pembelajaran PLH dilakukan berdasarkan Proses pengelolaan pembelajaran berbasis lingkungan dengan pola penguatan etika lingkungan sekolah yaitu penguatan pada Kegiatan Pendahuluan, Kegiatan Inti, kegiatan penutup dan evaluasi. Dengan beberapa kegiatan inti mendorong agenda menanam pohon di sekolah dan perawatannya, memngelola sampah dengan baik seperti membuang sampah pada tempat sampah hingga membangun komitmen kreativitas dalam memilah sampah hingga mengelola menjadi barang produktif dan inovatif. Mengadakan lomba inovasi pot bunga sebagai daya dukung penghijauan.

3. Hasil Belajar Pendidikan Lingkungan Hidup di SMA negeri 3 Sungai Kakap di kelola berdasarkan ranah kognitif, afektif dan psikomotorik. Daya dukung ini akan memberikan informasi apakah siswa memiliki komitmen yang kuat dalam penanaman Sikap peduli lingkungan dapat muncul setelah beberapa tahapan dipenuhi yaitu, pengetahuan (knowing), pelaksanaan (acting), dan kebiasaan (habbit). Hasil belajar siswa pada penilaian kognitif yang dilakukan di dalam kelas dengan nilai ratarata kelas 78,8 dengan prsentase ketutantasan $82,4 \%$ secara klasikal telah mencapai Kreteria ketuntasan Minimal $(\mathrm{KKM}) \geq 75$, oleh karena itu rata-rata kognitif siswa berdasarkan nilai rata-rata sangat baik. Penilaian afektif siswa SMA Negeri 3 Sungai Kakap dengan pendekatan melakukan kerja sama, pola perilaku jujur, tanggung jawab terhadap apa yang menjadi tugasnya, disiplin dalam menghadapi kehidupan. Sehingga diperoleh jumlah rata-rata afektif siswa di kelas 68,75\% masuk katagori Baik. Penilaian Psikomotorik dengan katagori penilaian bertanya, menjawab, bekerjasama, memberi pendapat, penguatan kondisi minat dengan nilai persentase $71 \%$ sebagai katagori Aktif. Aspek ini masuk dalam ranah aktif karena berkisar antara 70\%-84\%.

\section{DAFTAR PUSTAKA}

Abdul,Gafur. 2012. Desain Pembelajaran. Penerbit Ombak : Yogyakarta.

Atok Miftachul Hudha, Husamah, Abdulkadir Rahardjanto. 2019. Etika Lingkungan (Teori dan Praktek Pembelajarannya). Malang: Penerbit Universitas Negeri Malang. 
J U R N A L Jurnal Pendidikan Ilmu Pengetahuan Sosial Indonesia

Volum 5 Nomor 1 Bulan Maret Page 20 - 25

p-ISSN: 2477-6254 e-ISSN: 2477-8427

Mahi M. Hikmat.2011. Metode Penelitian Dalam Perspektif Ilmu Komunikasi dan Sastra, Yogyakarta: Graha Ilmu. 